\title{
Implementasi Smart Tourism sebagai Media Promosi Wisata di Sulawesi Barat
}

\author{
Asmawati $S^{* 1}$, Musyrifah ${ }^{2}$, Farid Wajidi ${ }^{3}$, Nuramsah Zulkarnaim ${ }^{4}$ \\ $1,2,3,4,5$ Universitas Sulawesi Barat \\ e-mail: *11asmawati.s@ unsulbar.ac.id, ${ }^{2}$ musyrifah@unsulbar.ac.id, ${ }^{3}$ faridwajidi@unsulbar.ac.id, \\ nuralamsahzulkarnaim@unsulbar.ac.id
}

\begin{abstract}
Abstrak
Potensi wisata yang dimiliki oleh Sulawesi Barat cukup potensial untuk dikembangkan, tetapi belum dikelola secara maksimal oleh pemerintah daerah maupun industri pariwisata. Sehingga masyarakat tidak tertarik untuk mengunjungi destinasi tersebut. Hal itu menjadi pokok permasalahan pada pariwisata di Sulawesi Barat serta kurangnya publikasi serta promosi yang dilakukan, sehingga dibutuhkan suatu suatu sistem yang dapat digunakan untuk mempromosikannya. Adapun tujuan penelitian ini untuk memudahkan wisatawan untuk mendapatkan informasi mengenai objek wisata yang ada di Sulawesi Barat dan akomodasi di sekitarnya, serta lokasi destinasi wisata tersebut. Jenis penelitian yang digunakan dalam penelitian ini adalah penelitian $R \& D$ dengan menggunakan metode prototype. Pembuatan aplikasi ini meliputi desain sistem menggunakan Use case Diagram, dan desain tampilan sistem. Sedangkan proses implementasi sistem menggunakan Codeigniter. Berdasarkan aspek program, content, penilaian pengguna, respon pengguna pada uji coba lapangan dengan jumlah enam puluh orang responden yang terdiri dari 20 orang wisatawan, 10 orang pemilik hotel dan 30 orang responden lainnya dari pihak pemerintah serta komunitas penggiat wisata, menunjukkan rerata 3,61 dengan persentase 90,21\% dengan kategori sangat baik, dapat disimpulkan bahwa pemanfaatan smart tourism sangat membantu dalam promosi wisata di daerah Sulawesi Barat
\end{abstract}

Kata Kunci : Media, Promosi, Smart Tourism, Sulawesi Barat, Wisata

\section{PENDAHULUAN}

Indonesia memiliki potensi yang cukup besar dalam menghasilkan devisa negara khususnya di sektor pariwisata, hal ini sejalan dengan pendapat Lubis dan Osman, bahwa pariwisata dapat memacu pertumbuhan ekonomi di Indonesia dan di negara-negara Asia Tenggara dan Asia pada umumnya jika dikembangkan secara optimal karena didukung oleh banyaknya destinasi wisata yang menarik dan potensial Sulawesi Barat dalam hal ini wisata lokal memiliki potensi yang cukup tinggi untuk membantu perekonomian daerah namun belum tereksplor secara maksimal.

Mertayasa (2017) mengemukakan bahwa perkembangan teknologi informasi dan penggunaan internet yang semakin luas dan cepat semakin mempermudah user dalam mengakses informasi secara akurat dimanapun tanpa terbatas ruang dan waktu. Hal tersebut menjadi celah daerah dalam memperkenalkan objek wisata yang dimiliki, ini sejalan dengan pendapat Soelistijadi yang menyatakan pariwisata merupakan sektor yang menguntungkan dan memiliki potensi yang dapat dikembangkan sebagai aset suatu daerah dan menjadi sumber penghasilan bagi masyarakat sekitar. Pemanfaatan teknologi ini memberikan keuntungan kepada pengelola objek wisata dan pemerintah khususnya Dinas Pariwisata di Sulawesi Barat, dengan mempermudah pengunjung yang berada di luar daerah untuk mengetahui informasi lebih jelas tentang tempat atau objek wisata yang akan dikunjungi.

Penelitian yang dilakukan oleh Saputra menjelaskan bahwa promosi wisata menggunakan website dapat memberikan informasi kepada wisatawan dalam pencarian data, penelitian lain yang dikemukakan oleh Cheril Mouren mengatakan bahwa promosi wisata menggunakan web memudahkan wisatawan untuk mendapat informasi mengenai pariwisata di Kabupaten Minahasa.

Penelitian sebelumnya yang dilakukan oleh (Laode, dkk, 2019) menjelaskan bahwa aplikasi berbasis GIS (Geographic Information System) dapat digunakan untuk melihat potensi wisata yang dapat

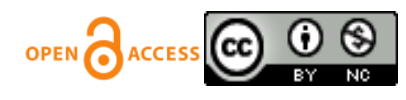


dikembangkan. Penelitian lainnya yang dilakukan oleh A. Darman Umagapi mengatakan bahwa dengan mempromosikan objek wisata menggunakan web memberikan dampak yang signifikan karena hal tersebut memberikan kemudahan bagi para wisatawan dalam mencari informasi mengenai objek-objek wisata di Kota Ternate.

Menurut ghozali (2015) dalam penelitiannya sistem informasi berbasis website para pengunjung dapat mencari informasi mengenai objek-objek wisata yang akan dikunjungi, dan mengetahui lokasi dari tempat wisata tersebut, serta akomodasi yang digunakan untuk mencapai ke Kabupaten Kepulauan Sangihe sehingga para wisatawan dapat mengetahui informasi yang lebih akurat mengenai tempat yang akan dikunjungi.

Sulawesi Barat memiliki Potensi wisata yang cukup memadai,tetapi belum dikelola secara maksimal oleh pemerintah daerah maupun industri pariwisata. Sehingga masyarakat tidak memiliki minat untuk melakukan traveling. Hal tersebut menjadi pokok permasalahan pada pariwisata di Sulawesi Barat dan publikasi serta promosi yang dilakukan masih minim, pada umumnya masyarakat belum tahu apa destinasi wisata di Sulawesi Barat. Ironisnya, warga setempat pun jika ditanya apa destinasi wisata di sana, umumnya mereka kebingungan dalam memberikan jawaban. Berdasarkan permasalahan yang telah dipaparkan sebelumnya, dibutuhkan sebuah sistem yang dapat memberikan informasi mengenai destinasi wisata yang ada di Sulawesi Barat beserta informasi mengenai hotel, serta akomodasi lainnya menjadi salah satu pertimbangan dalam pemilihan destinasi wisata. Sehingga dibutuhkan sebuah aplikasi pariwisata berupa aplikasi smart tourism yang dapat merekomendasikan tempat dan fasilitas wisata serta preferensi untuk wisatawan.

\section{METODE PENELITIAN}

Jenis penelitian yang digunakan adalah penelitian $\mathrm{R} \& \mathrm{D}$ (Research and Development) menggunakan metode prototype dalam pengembangan sistem smart tourism, yang bertujuan untuk mengimplementasikan aplikasi ini dalam promosi wisata di Sulawesi Barat. Metode prototype merupakan bagian dari pengembangan produk yang menggunakan logika maupun fisik interface eksternal yang ditampilkan. Metode pendekatan ini, memaksimalkan komunikasi antara konsumen dan tim pengembang dalam mengklarifikasi kebutuhan dan interpretasi mereka dalam membangun sebuah sistem yang diinginkan (Simarmata, 2010).

Tahap analisis dan desain sistem, terutama untuk proses transaksi, di mana komunikasi yang ditampilkan lebih mudah dipahami. Semakin banyak interaksi antara user dan komputer maka besar pula manfaat yang diperoleh.Ketika proses pengembangan sistem informasi akan lebih cepat dan membuat pengguna akan lebih interaktif dalam proses pengembangannya (Ogedebe, 2012).

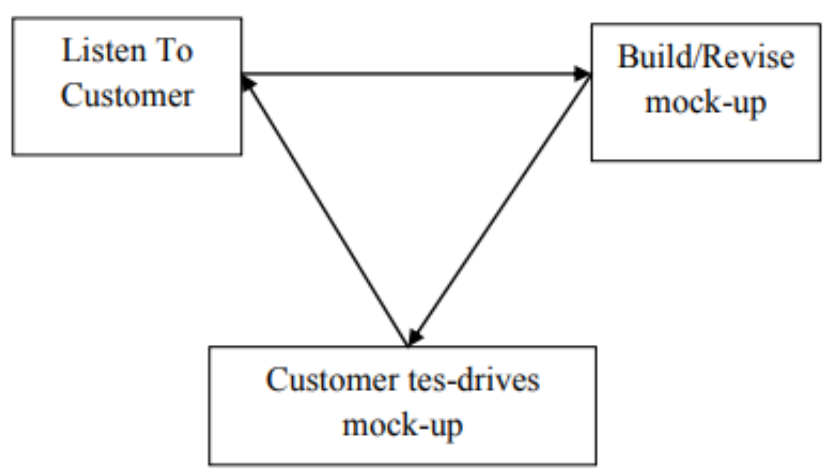

Gambar 1 Metode prototyping

(Ogedebe, 2012)

Prototyping dimulai dengan pengumpulan kebutuhan, melibatkan pengembang dan pengguna sistem untuk menentukan tujuan, fungsi dan kebutuhan operasional sistem. Langkah Langkah dalam prototyping adalah sebagai berikut:
1. Listen To Customer
2. Revise Mock-Up
3. Customer test-drives mock-up 


\subsection{Teknik Pengumpulan Data}

Pengumpulan data dilakukan melalui observasi, wawancara, dan kuesioner kepada wisatawan, penggiat wisata, pemerintah, pengelola objek wisata yang berada di Sulawesi Barat. Kuesioner dibuat untuk menilai fungsionalitas system dan beberapa aspek penting yang ada di dalam system smart tourism. Kuesioner dibuat menggunakan Skala Likert, dimana Skala Likert digunakan untuk mengetahui tanggapan seseorang ataupun sekelompok orang mengenai kejadian sosial yang telah ditentukan dengan cara tertentu oleh peneliti, yang kemudian dijadikan acuan sebagai faktor yang akan diteliti (Sugiyono, 2015).

Penelitian ini dilakukan di Sulawesi Barat, adapun subjek yang diteliti pada penelitian ini yaitu objek wisata yang ada di Sulawesi Barat, pelaku wisata, pemerintah dalam hal ini dinas pariwisata, hotel, rumah makan dan pemilik UMKM, sampel yang digunakan menggunakan metode purposive sampling, metode ini diambil dengan pertimbangan tertentu sesuai dengan tujuan penelitian (Arikunto, 2013).

\subsection{Teknik Analisis Data}

Teknik analisis data yang digunakan dalam penelitian ini adalah analisis deskriptif dengan pendekatan rumus persentase. Analisis deskriptif digunakan untuk menganalisis dan mendeskripsikan data dari penelitian yang telah dikumpulkan. (Sujadna, 2011).

$P=\frac{F}{N} \times 100 \%$

dengan $\mathrm{P}$ adalah persentase yang diperoleh, $\mathrm{F}$ adalah frekuensi dari variabel yang diuji, dan $\mathrm{N}$ adalah jumlah responden.

\subsection{Analisis Kebutuhan (Listen to Customer)}

Beberapa masalah yang diperoleh pada Perancangan sistem smart tourism dan solusi dari permasalah tersebut, yaitu :

1. Analisis Masalah

a. Terbatasnya informasi mengenai destinasi wisata yang ada di Sulawesi Barat

b. Keterbatasan promosi wisata, hotel dan UMKM yang dilakukan oleh industri pariwisata dan pihak-pihak terkait

c. Proses pemesanan dan pembayaran dilakukan secara manual

2. Solusi yang diberikan

a. Map GPS

Aplikasi ini sudah terintegrasi dengan Google Maps sehingga memudahkan user dalam mencari lokasi destinasi wisata yang diinginkan.

b. Pemesanan Hotel dan akomodasi lainnya dapat dipesan secara langsung

c. Prose pembayaran dipermudah untuk wisatawan dan pemilik hotel serta pengelola objek wisata dalam otorisasi proses pembayaran menggunakan kartu kredit, transfer antar bank, ataupun pembayaran langsung.

d. Up-to-date system Data Informasi mengenai destinasi wisata dan event-event yang diselenggarakan oleh pemerintah yang akurat dan selalu update berkala.

e. Levelisasi Akses Masing-masing user diberikan hak akses yang berbeda tergantung dengan kewenangan yang diberikan.

f. Security System Mencegah dari hal-hal yang tidak diinginkan maka login sistem di aplikasi melakukan enkripsi dengan MD5.

g. Mobile based system Aplikasi ini dapat diakses dimana saja dan kapan saja secara online dari smartphone yang terkoneksi dengan internet.

h. User-Friendly Interface Tampilan yang memudahkan user dalam mengakses aplikasi dan nyaman saat penggunaanya. 
Perancangan sistem yang dibuat dan berdasarkan dari beberapa permasalahan yang ada, maka diperlukan penentuan kebutuhan dari sistem yang akan dibangun untuk mendapat hasil analisis yang optimal. Pada Perancangan aplikasi ini, terdapat beberapa hal yang diperlukan dalam perancangannya, yaitu:

1. Kebutuhan Fungsional

a. Aplikasi dapat menampilkan informasi destinasi wisata, hotel, rumah makan, dan transportasi yang dibutuhkan

b. Aplikasi dapat menampilkan peta lokasi destinasi wisata, hotel, rumah makan, dan transportasi yang dibutuhkan

c. Aplikasi dapat melakukan pemesanan kamar Hotel, Rumah makan

d. Aplikasi dapat melakukan konfirmasi pembayaran kamar Hotel, Rumah makan

2. Kebutuhan Non Fungsional

a. Aplikasi dapat mempermudah pengguna dalam mencari informasi mengenai destinasi wisata

b. Aplikasi dapat memberi petunjuk menuju lokasi yang dipilih pengguna.

c. Aplikasi dapat dijalankan diberbagai perangkat Mobile yang terkoneksi dengan jaringan internet.

\subsection{Revise Mock-Up (Perancangan Sistem)}

1. Rancangan use case diagram smart tourism

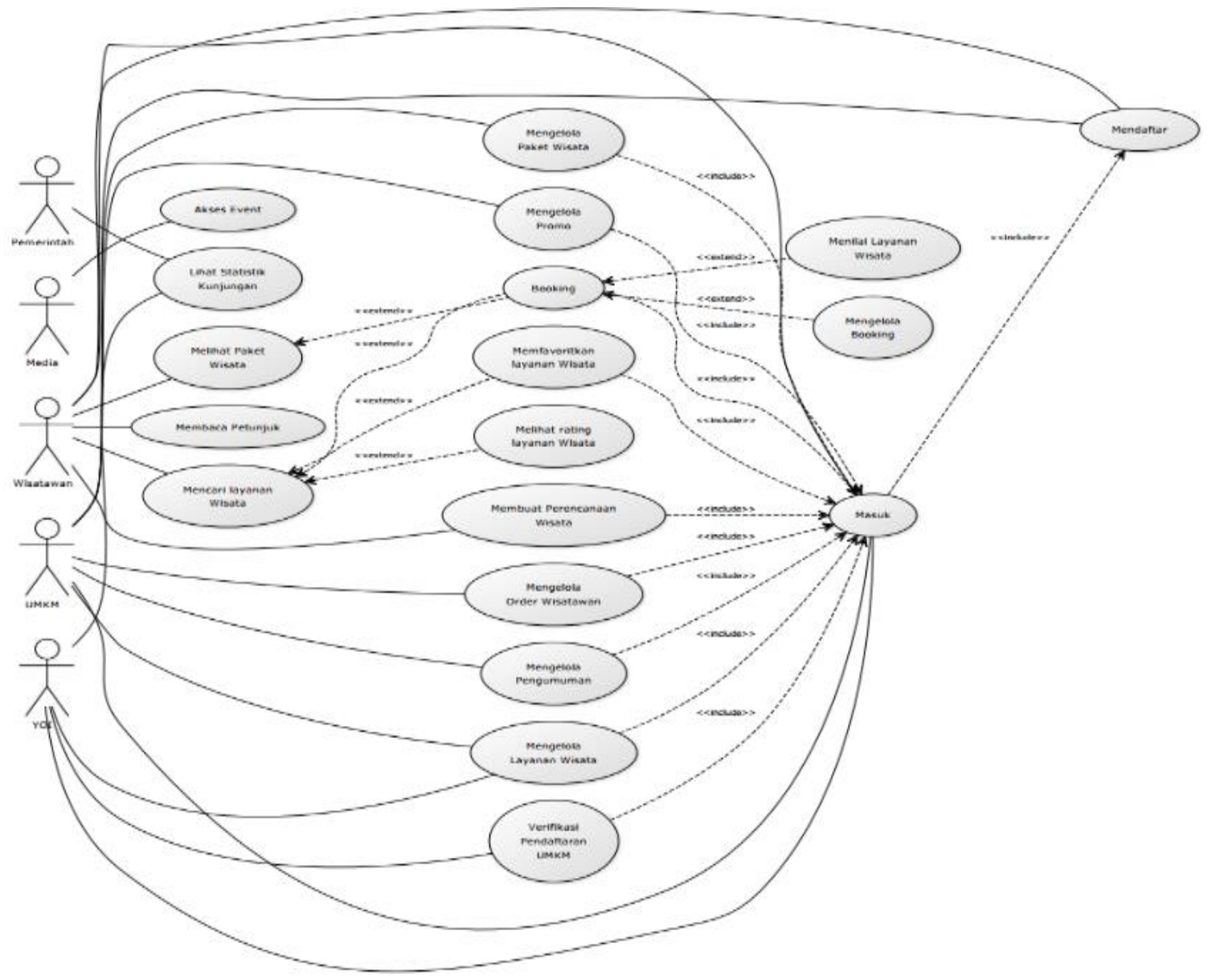

Gambar 2. Use case diagram smart tourism 


\subsection{Customer test-drives mock-up}

Customer test-drives mock-up yaitu tahap terakhir dengan melakukan pengujian sistem oleh pengguna. Mock-up yang telah dibuat harus diuji untuk menentukan perilakunya dan mengumpulkan keluaran sehingga didapat produk yang sesuai dengan keinginan pengguna. Pengujian sistem dilakukan untuk melihat kesesuaian sistem dengan spesifikasi yang diberikan dan mencari kesalahan yang mungkin masih ada. Kesalahan yang ditemukan kemudian diperbaiki hingga sesuai dengan kebutuhan pengguna. Proses revisi dan pengujian terhadap mock-up dilakukan secara iteratif hingga didapatkan sistem yang sesuai dengan yang diinginkan oleh pengguna.

Metode pengujian yang digunakan pada adalah metode deskriptif presentase. Metode ini digunakan untuk menguji aspek functional suitability, aspek performance efficiency, dan aspek compatibility system smart tourism. Deskriptif presentase ini diolah dengan cara frekuensi dibagi dengan jumlah responden dikali $100 \%$ (Sujadna, 2011).

\section{HASIL DAN PEMBAHASAN}

Aplikasi smart tourism dikelola oleh PT YOY Manajemen Internasional dan memungkinkan mitra UMKM dalam hal ini merupakan pengelola usaha pariwisata dan akomodasi wisata untuk melakukan pendaftaran dan menambahkan informasi terkait usaha pariwisata mereka.

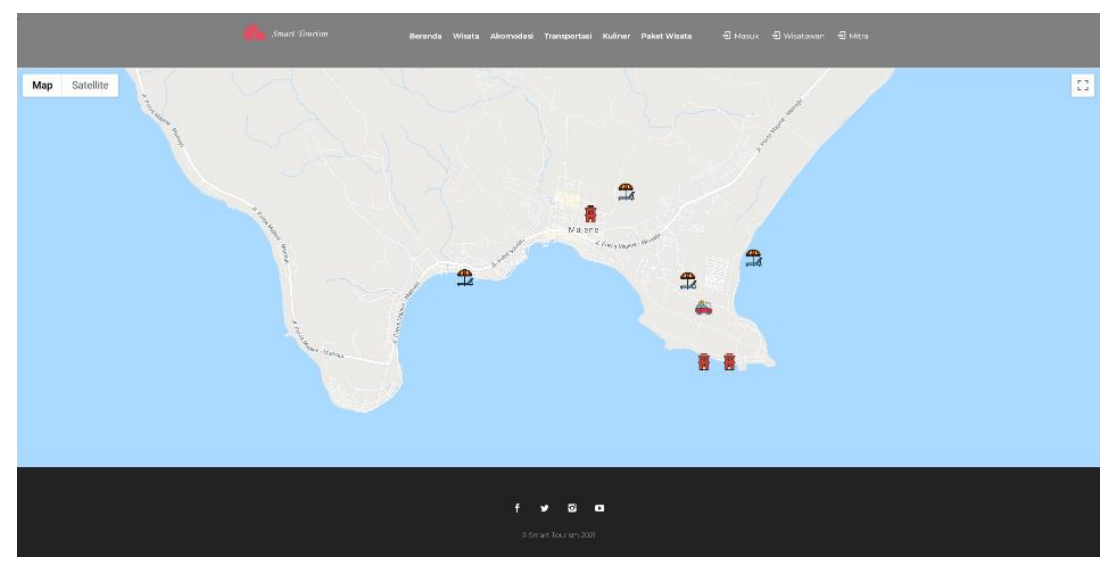

Gambar 3 Tampilan antar muka Mandar Tour

\subsection{Admin (You Manajemen)}

Fungsi administrator (Admin) merupakan fungsi pengaturan dan pengelolaan aplikasi dengan hal tertinggi pada aplikasi smart tourism Mandar Tour yang akan dikembangkan di Sulawesi Barat. Fungsi pengelolaan aplikasi ini dipegang oleh pihak PT YOY Manajemen Internasional sebagai mitra pengembangan aplikasi smart tourism Mandar Tour yang dikembangkan oleh Universitas Sulawesi Barat. Berikut ini daftar kebutuhan fungsional yang harus dapat dijalankan oleh Admin pada aplikasi smart tourism Mandar Tour:

1. Login sebagai admin

2. Verifikasi berkas mitra

3. Mengelola pendaftaran mitra

4. Mengelola Akun mitra

5. Mengelola Akun Admin

\subsection{Wisatawan}

Wisatawan dapat dikatakan sebagai pengguna utama aplikasi smart tourism Mandar Tour ini. Wisatawan dapat merupakan wisatawan lokal maupun wisatawan nasional. Dengan aplikasi smart tourism Mandar Tour, wisatawan diharapkan dapat lebih mudah dalam menemukan destinasi atau paket wisata yang ada di Sulawesi Barat dan bertransaksi melalui aplikasi.

Berikut ini daftar kebutuhan fungsional yang harus dimiliki oleh pengguna wisatawan pada aplikasi smart tourism Mandar Tour: 
1. Registrasi atau pendaftaran

2. Login \& Logout

3. Melihat Layanan Wisata via Maps

4. Melakukan Pencarian layanan wisata

5. Melakukan pemesanan layanan wisata

\subsection{Mitra}

Mitra merupakan pelaku usaha pariwisata dan akomodasi pariwisata yang bermitra dengan PT YOY Manajemen Internasional sebagai pengelola aplikasi Smart Tourism Mandar Tour. Tujuan utama mitra pada Smart Tourism Mandar Tour ini yaitu untuk memasarkan layanan pariwisata atau akomodasi wisata yang mereka tawarkan. Berikut ini daftar kebutuhan fungsional yang harus dimiliki oleh pengguna Mitra:

1. Registrasi atau pendaftaran

2. Login \& Logout

3. Menambahkan layanan wisata

4. Mengelola layanan wisata

5. Mengelola pemesanan layanan wisata

\subsection{Pemerintah}

Pemerintah adalah Pemerintah Provinsi Sulawesi Barat melalui Dinas Pariwisata Provinsi Sulawesi Barat. Pada aplikasi Smart Tourism Mandar Tour ini pemerintah dapat mengakses informasi statistik kunjungan wisatawan di Sulawesi yang menggunakan layanan aplikasi Smart Tourism Mandar Tour sebagai dasar dalam pengambilan kebijakan di bidang pariwisata di Sulawesi Barat.

\subsection{Media}

Media merupakan perusahaan media resmi yang terdaftar. Media dapat mendaftar sebagai media dan mendapatkan akses informasi agenda kegiatan wisata yang ada di Sulawesi Barat sebagai sumber pemberitaan.

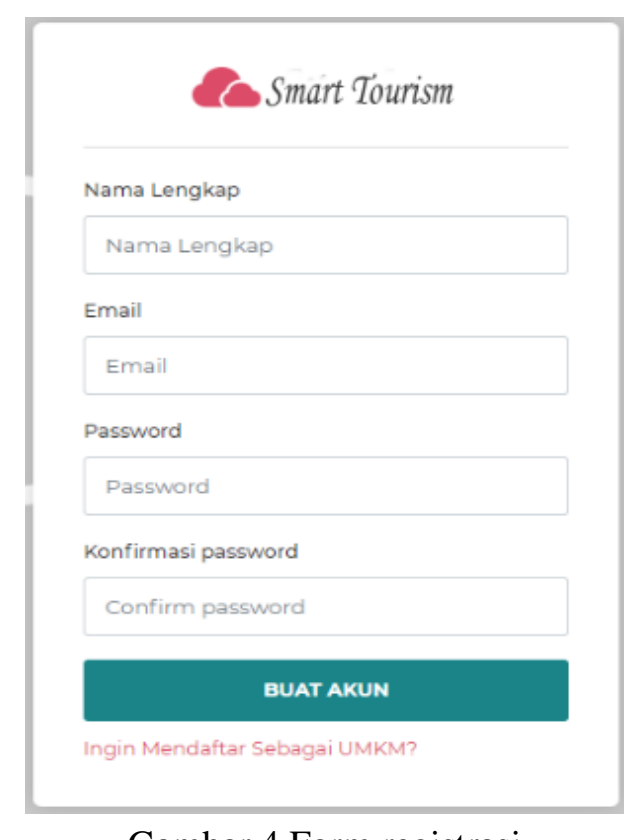

Gambar 4 Form registrasi

Form registrasi digunakn untuk membuat akun dan mendaftar sebagai member pada aplikasi smart tourism baik sebagai wisatawan, dan sebagai mitra dalam hal ini pengelola objek wisata, pemilik hotel dan rumah makan. 


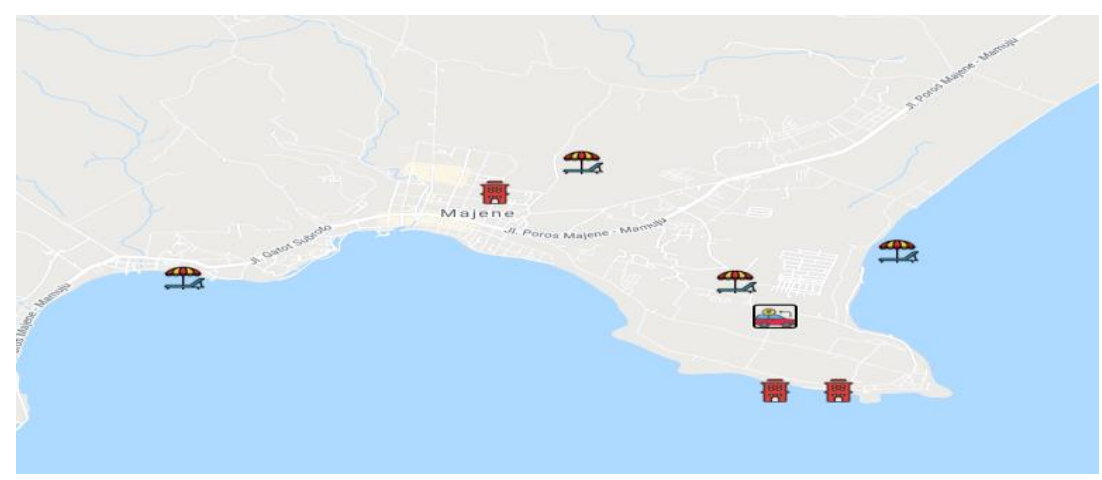

Gambar 5 layanan wisata

Layanan wisata akan tampil pada saat pertama kali kita membuka Aplikasi smart tourism yang menampilkan destinasi wisata terdekat dengan titik lokasi wisatawan.

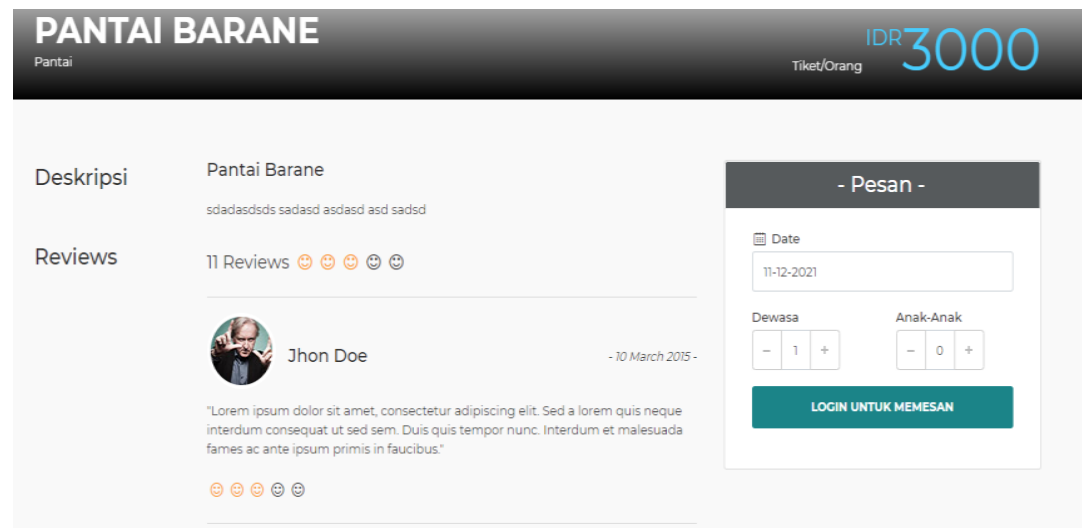

\section{Gambar 6 destinasi wisata}

Destinasi wisata memberikan informasi mengenai objek wisata dan komentar serta review dari pengunjung mengenai objek wisata tersebut seperti yang terlihat pada gambar 6 .

Pengujian aplikasi smart tourism dengan menggunakan kuesioner yang telah dibuat dengan jumlah responden 60 orang yang terdiri 20 orang wisatawan, 10 orang pemilik hotel dan 30 orang responden lainnya dari pihak pemerintah serta komunitas penggiat wisata. Tahap uji coba dilakukan untuk menghasilkan aplikasi yang bermanfaat. Dengan melihat 4 aspek dari aplikasi tersebut yaitu: kualitas aplikasi, penggunaan aplikasi, kepuasan pengguna, dan dampak bagi pengelola objek wisata, pemilik hotel, pemerintah dan UMKM.

Tabel 1. Hasil Analisis Uji Coba Aplikasi

\begin{tabular}{|c|c|l|c|c|c|}
\hline No & Aspek & \multicolumn{1}{c|}{ Indikator } & Rerata & Persentase & Kesimpulan \\
\hline 1 & Program & Perangkat lunak & 4.00 & $100 \%$ & Sangat baik \\
\hline & & Praktis & 3.80 & $95 \%$ & Sangat baik \\
\hline & & Efektif & 3.25 & $81.25 \%$ & Baik \\
\hline & & Buku manual & 4.00 & $100 \%$ & Sangat baik \\
\hline \multicolumn{2}{|c|}{ Keseluruhan indikator } & $\mathbf{3 . 7 6}$ & $\mathbf{9 4 \%}$ & Sangat baik \\
\hline 2 & Content (isi) & Keterbacaan teks & 4.00 & $100 \%$ & Sangat baik \\
\hline & & Kualitas Gambar & 3.50 & $87.50 \%$ & Sangat baik \\
\hline & & Keserasian Warna & 3.50 & $87.50 \%$ & Sangat baik \\
\hline & & Tombol & 3.25 & $81.25 \%$ & Baik \\
\hline
\end{tabular}


https://jurnal.unsulbar.ac.id/index.php/saintifik

\begin{tabular}{|c|c|l|c|c|c|}
\hline No & Aspek & \multicolumn{1}{|c|}{ Indikator } & Rerata & Persentase & Kesimpulan \\
\hline \multicolumn{2}{|c|}{ Keseluruhan indikator } & $\mathbf{3 . 5 6}$ & $\mathbf{8 9 \%}$ & Sangat baik \\
\hline 3 & $\begin{array}{l}\text { Penilaian } \\
\text { Pengguna }\end{array}$ & Kualitas aplikasi & 3.50 & $87.50 \%$ & Sangat baik \\
\hline & $\begin{array}{l}\text { Penggunaan } \\
\text { aplikasi }\end{array}$ & 3.50 & $87.50 \%$ & Sangat baik \\
\hline & $\begin{array}{l}\text { Kepuasan } \\
\text { pengguna }\end{array}$ & 3.50 & $87.50 \%$ & Sangat baik \\
\hline & $\begin{array}{l}\text { Dampak bagi } \\
\text { UMKM dan } \\
\text { pemerintah }\end{array}$ & 3.50 & $87.50 \%$ & Baik \\
\hline \multicolumn{2}{|c|}{ Keseluruhan indikator } & $\mathbf{3 . 5 0}$ & $\mathbf{8 7 . 5 0 \%}$ & Sangat baik \\
\hline
\end{tabular}

Tabel 1 untuk aspek program berada pada kategori sangat baik dengan nilai rata-rata 3,76 dengan persentase $94 \%$, ini menunjukkan bahwa program aplikasi smart tourism menurut responden yang diuji ratarata berpendapat sangat baik. Aspek content (isi) dari aplikasi smart tourism berada pada kategori sangat baik dengan rerata 3,56 dan persentase 89\%, menunjukkan bahwa content aplikasi sangat baik menurut responden yang diuji coba lapangan rata-rata berpendapat sangat baik. Aspek penilaian pengguna pada kategori sangat baik dengan rerat 3,5 dan persentase $87,5 \%$, bahwa kepuasan pengguna menurut responden yang diuji coba lapangan rata-rata berpendapat sangat baik.

Berdasarkan aspek program, content, penilaian pengguna, respon pengguna pada uji coba lapangan dengan jumlah enam puluh orang responden yang terdiri dari 20 orang wisatawan, 10 orang pemilik hotel dan 30 orang responden lainnya dari pihak pemerintah serta komunitas penggiat wisata, menunjukkan rerata 3,61 dengan persentase $90,21 \%$ dengan kategori sangat baik, dapat disimpulkan bahwa pemanfaatan smart tourism sangat membantu dalam promosi wisata di daerah Sulawesi Barat

\section{KESIMPULAN}

Berdasarkan hasil dan pembahasan sebelumnya maka disimpulkan bahwa hasil dari penelitian ini adalah smart tourism dapat berjalan sesuai dengan yang diharapkan serta memberikan informasi kepada wisatawan mengenai destinasi wisata yang ada di Sulawesi Barat. Dengan adanya sistem smart tourism, dapat memudahkan industri pariwisata dengan mempromosikan dan memberikan informasi mengenai destinasi wisata. Memudahkan para wisatawan dalam mencari informasi mengenai objek-objek wisata yang akan dikunjungi, dan mengetahui lokasi dari tempat wisata tersebut, serta akomodasi yang digunakan untuk mencapai objek wisata yang ada di Sulawesi Barat.

\section{DAFTAR PUSTAKA}

A. Gozali, "Pembuatan Sistem Informasi Pariwisata Kota Samarinda Berbasis Web," Jurnal Ilmiah Mahasiswa Universitas Surabaya, vol. 4, no. 1, pp. 1-11, 2015.

Arikunto, Suharsimi. 2013. Prosedur Penelitian Suatu Pendekatan Praktik. 15th ed. Jakarta: Rineke Cipta.

C. M. Lengkong, R. Sengkey, and B. A. Sugiarso, "Sistem Informasi Pariwisata Berbasis Web di Kabupaten Minahasa," Jurnal Teknik Informatika, vol. 14, no. 1, pp. 15-20, 2019, doi: 10.35793/jti.14.1.2019.23780.

D. M. Mertayasa and A. R. Yambese, "Sistem Informasi Pariwisata Pantai Berbasis Web," Elektron. Sist. Inf. dan Komput., vol. 3, no. 1, pp. 51-61, 2017.

D. Umagapi and A. Ambarita, "Sistem informasi geografis wisata bahari pada dinas pariwisata Kota Ternate," Jurnal Ilmiah Ilkominfo - Jurnal Ilmu Komputer dan Informatika, vol. 1, no. 2, 2018

K. Saputra, "Perancangan sistem informasi pariwisata berbasis website sebagai media promosi di Singkawang Kalimantan Barat," Jurnal Ekonomi Dan Bisnis Indonesia, vol. 2, no. 1, 2017

Lubis, Zulkarenain \& Osman, Abdullah. 2014. Indonesian Tourism Sector: A Potential Sector That Has Not Been Optimized. Australian Journal of Basic and Applied Sciences, 8(23): 286-290.

Implementasi Smart Tourism sebagai Media Promosi Wisata di Sulawesi Barat (Asmawati S, dkk) 
https://jurnal.unsulbar.ac.id/index.php/saintifik

R. Soelistijadi, "Sistem Informasi Pariwisata Berbasis Web: Studi Kasus Fasilitas Penginapan Di Wilayah Provinsi Yogyakarta,” J. Din. Inform., vol. 7, no. 1, pp. 59-67, 2015

Simarmata, J. 2010. Rekayasa Perangkat Lunak. Yogyakarta: Andi.

Sugiyono. 2015. Metode Penelitian Kuantitatif, Kualitatif, Dan R\&D. Bandung: Alfabeta.

Sujadna, Nana. 2011. Penilaian Hasil Proses Belajar Mengajar. Bandung: PT Remaja Rosdakarya. 